\title{
Impact of IL-4 polymorphisms on head and neck cancer susceptibility in the Chinese Han population
}

\author{
Huajing Li \\ The First Affiliated Hospital of Xi'an Jiaotong University.
}

Na Duan

The First Affiliated Hospital of Xi'an Jiaotong University.

Qing Zhang

The Second Affiliated Hospital of Xi'an Jiaotong University.

Yuan Shao ( $\square$ shaoyuan6688@163.com )

The affiliated hospital of Xi'an jiaotong university. https://orcid.org/0000-0002-6983-5300

Research article

Keywords: IL-4, Head and neck cancer (HNC), single nucleotide polymorphisms (SNPs), case-control study

Posted Date: June 3rd, 2019

DOI: https://doi.org/10.21203/rs.2.10013/v1

License: (c) (i) This work is licensed under a Creative Commons Attribution 4.0 International License. Read Full License 


\section{Abstract}

Background: Head and neck cancer (HNC) is the sixth most frequent malignancy in the world. Interleukin 4 (IL-4) has been proved to be closely related to the occurrence and development of cancer. The objective of this research was to assess the association of IL-4 genetic polymorphisms with HNC risk in Chinese Han population. Methods: Six single nucleotide polymorphisms (SNPs) of IL-4 gene were successfully genotyped using Agena MassARRY in $535 \mathrm{HNC}$ patients and 538 healthy controls. Under multiple genetic models, stratification analysis and haplotype analysis, odds ratio (OR) and 95\% confidence interval (Cl) were calculated to assess the association between SNPs and HNC risk. Results: The polymorphism, rs2243250, in the IL-4 gene was significantly associated with an increased HNC risk in the allele model $(P<0.05)$. In the genetic model, the polymorphisms rs2243250, rs2243267 and rs2243270 in IL-4 gene conferred an increased risk of HNC ( $<$ < 0.05). Gender stratification analysis showed that in males, rs2243250, rs2243267, rs2243270 and rs2243289 were associated with an increased risk of HNC $(P<0.05)$, while rs2243283 was associated with a decreased risk of HNC in males $(P<0.05)$. Besides, we have not found any association between six SNPs in IL-4 gene and HNC risk in females. Further haplotype analysis revealed that the haplotype CTGAC was significantly associated with a decreased risk of HNC. Conclusion: This study provides an evidence for polymorphism of IL-4 gene associated with the development of HNC in the Chinese Han population.

\section{Introduction}

Head and neck cancer (HNC) is found in the oral cavity, pharynx, nasal cavity, paranasal sinuses, larynx, and salivary glands1, ranking the sixth most frequent malignancy worldwide [1]. Although HNC is treated with a comprehensive treatment involving radiation, chemotherapy, and surgical treatment modalities, its mobility remains high. HNC has a mortality rate of $40-50 \%$ and is detected in 600,000 cases annually worldwide, accounting for $\sim 3.8 \%$ of global cancer cases and $\sim 3.6 \%$ of all cancer-associated mortality $[2,3]$. The etiology of HNC is multifactorial, and epidemiological evidence suggests that traditional risk factors such as tobacco, alcohol use, occupational exposure and use of external substances are well-known causal factors for HNC development [4]. However, more evidences demonstrated that genetic factors also play more important roles in the pathogenesis of HNC, and further studies have confirmed that the genetic susceptibility of HNC was closely related to the mutations of several genes [5].

Inflammation is a complex response at the cellular and tissue levels that can promotes tumorigenesis by stimulating angiogenesis [6], damaging DNA [7] and stimulating cell proliferation [8]. Interleukin 4 (IL-4) is an anti-inflammatory immunosuppressive cytokin, and is produced by activated CD4+ T cells, mast cells, and basophils [9]. IL-4 is responsible for inducing the production of IgE by B cells, and it can antagonize the function of IFN- $y$ and inhibit the activation of macrophages [10]. There is some evidence that $I L-4$ signaling promotes malignancy through its immunosuppressive effect on T cells, increased proliferation of cancer cells, and resistance to apoptosis [11, 12]. Vasilena et al. reported that $I L-4$ can promote cancer growth and invasion by inducing the cathepsin activity in tumor-associated macrophages (TAM) both in vivo and in vitro [13]. It also has been reported that $I L-4$ was related to humoral immune response, and may regulate the growth of head and neck (SCCHN) cell lines by a paracrine mechanism [14]. The serum samples of patients with HNSCC were detected to contain abnormal levels of inflammatory cytokines, such as lower IFN- $y$ and IL-13 levels, compared with the control mean level [15]. The expression of $I L-4$ was up regulated in several human malignancies including breast, colon, pancreatic, ovarian, and lung cancer $[16,17]$. Besides, there is evidence receptors for interleukin $4(I L-4 R)$ are preferentially expressed on the surface of a variety of solid tumors including SCCHN [18, 19]. IL-4R-directed cytotoxin has pronounced antitumor activity against SCCHN in animal models of human disease [20]. All the above studies indicated that $I L-4$ gene is closely related to the susceptibility of HNC.

Furthermore, the polymorphism of $I L-4$ is associated with genetic susceptibility to a variety of diseases. For example, studies by Zoe et al. have shown that the functional polymorphisms affecting gene expression of IL-4 are strongly associated with increased risk for oral cancer [21]. Ms-hsui et al. showed that the genotype distribution of C/T polymorphism in the $I L-4$ gene promoter region was significantly different between patients and controls, and $590 \mathrm{C} / \mathrm{T}$ (rs2243250) polymorphism could increase the risk of esophageal cancer [22].

However, few studies have examined the association of IL-4 polymorphisms with the risk of HNC. Therefore, we conducted a case-control study to investigate the relationship between IL-4 polymorphisms (rs2243250, rs2227284, rs2243267, rs2243270, rs2243283 and rs2243289) and the susceptibility to HNC in the Chinese Han population. Our results may provide new insights into understanding the mechanisms of HNC and contribute to the early prevention and targeted treatment of HNC.

\section{Methods}

\section{Study subjects}


Using a case control design, 267 patients with newly diagnosed $\mathrm{HNC}$ and 302 healthy controls were recruited. All the subjects were recruited from the First Affiliated Hospital of Xi'an Jiaotong University. All participants were genetically unrelated Chinese Han population. None of the patients had received radiotherapy, chemotherapy, or endocrine therapy before blood collection. Patients with HNC were selected from the Department of Oncology. The HNC diagnoses of all patients were confirmed by histopathological analysis. Patients with a history of other types of cancers or who underwent radiotherapy or chemotherapy were excluded were excluded in this study. The control group was healthy individuals, and had no history of tumor, no genetic family history of tumors, and no tumor was found during the physical exam. Participants were selected without restrictions on age, gender, or disease stage.

\section{DNA Extraction}

The peripheral blood samples from HNC patients and controls were collected into vacutainers containing ethylene diaminetetraacetic acid (EDTA) and stored at -80C until further analysis. GoldMag-Mini Whole Blood Genomic DNA Purification Kit (GoldMag Co. Ltd. Xi'an City, China) was used to extract genomic DNA from peripheral blood leukocytes in whole blood samples according to the manufacturer's agreement, and spectrophotometer (NanoDrop 2000; Thermo Fisher Scientific, Waltham, MA, USA) was used to determine the purity and concentration of the extracted DNA.

\section{SNPs selection and genotyping}

Six SNPs (rs2243250, rs2227284, rs2243267, rs2243270, rs2243283 and rs2243289) in the IL-4 gene, which the minor allele frequencies beyond $5 \%$ in global population, were selected from the 1000 Genomes database (http://www.internationalgenome.org/) and dbSNP database (http://www.bioinfo.org.cn/relative/dbSNP\%20Home\%20Page.htm) for further genotyping. We exploited online software Agena Bioscience Assay Design Suite Version 2.0 (https://agenacx.com/online-tools/) to design a multiplexed SNP MassEXTENDED assay. Primers for SNP identification during the experiment are presented in Table 1. SNPs were genotyped using the standard protocol recommended by the Agena MassARRAY platform with iPLEX gold chemistry (Agena Bioscience, San Diego, CA, USA), and data were analyzed using Agena Bioscience TYPER software (version 4.0).

\section{Statistical Analysis}

Differences in the characteristics of the case and control study populations were analyzed using $\chi 2$ tests for categorical variables and Welch's t-tests for continuous variables. The lower frequency alleles were considered to be the risk allele in all analyses. Departure from Hardy Weinberg equilibrium (HWE) of genotypic distribution of each SNP in controls was analyzed using Fisher s exact test. Pearson's $x 2$ test was applied to compare the allele and genotype frequencies between the HNC patients and healthy subjects. Odds ratios (ORs) and $95 \%$ confidence interval $(95 \% \mathrm{Cl})$ were calculated using unconditional logistic regression analysis after adjusting for age and sex. Genotypic model analysis (codominant, dominant, recessive, and log-additive) implemented by SNPstats software (https://www.snpstats.net/start.htm) were used to assess the relationship between selected SNPs and the risk of HNC in Chinese Han people $[23,24]$. Haploview software package (version 4.2) and SHEsis software platform were used for analysis, including LD, haplotype construction and genetic association of polymorphic loci.

Microsoft Excel (Microsoft Corporation, Redmond, WA, USA) and the SPSS 18.0 statistical package (SPSS, Chicago, IL, USA) were performed for statistical analysis [25]. In the study, all the $P$-values were two-sided, and $P=0.05$ was considered the cutoff for statistical significance.

\section{Results}

\section{Demographic and clinical characteristics}

A case control study containing $535 \mathrm{HNC}$ patients with a mean age of $46.80 \pm 15.08$ and 538 healthy controls with a mean age of $46.94 \pm$ 13.79 was performed. Table 2 listed the demographics and clinical information of the cases and controls enrolled in the present study. Gender, age, nasopharyngeal cancer and thyroid cancer were not statistically significant in the cases and controls $(P>0.05)$, while lymph node metastasis and staging were significantly different between the cases and controls $(P<0.05)$.

\section{Hardy-Weinberg equilibrium and allelic frequency analyses}

Table 3 summarizes the basic characteristics of the SNPs in the study population, and shows that all the six SNPs from controls were in accordance with HWE $(P>0.05)$. The average SNPs call rate was more than $95 \%$ in cases and controls. We compared the differences in frequency distributions of alleles between cases and controls compared by Pearson's $\chi 2$ test and found only the minor allele " $C$ " of 
rs2243250 from IL4 was significantly associated with an increased risk of $\mathrm{HNC}$ in the study population $(P=0.044, \mathrm{OR}=1.23,95 \% \mathrm{CI}=$ $1.01-1.50)$.

\section{Genetic model analysis of the association between selected SNPs and HNC risk}

Furthermore, we hypothesized that harboring the minor allele of each SNP was a risk factor, compared with possessing the wild-type allele. Four genetic models (codominant, dominant, recessive and log-additive) were applied to assess the relationships between the SNPs and risk of HNC using an unconditional logistic regression analysis with adjustments for age and gender (Table 4). Our analyses showed that rs2243250 was associated with an increased risk of HNC both before and after adjusted with age and gender under the codominant model (crude OR $=2.10,95 \% \mathrm{Cl}: 1.16-3.79, P=0.014$; adjust $\mathrm{OR}=2.10,95 \% \mathrm{Cl}: 1.16-3.79, P=0.014$ ), the recessive model (crude $\mathrm{OR}=2.02,95 \% \mathrm{Cl}: 1.13-3.62, P=0.018$; adjust $\mathrm{OR}=2.02,95 \% \mathrm{Cl}: 1.13-3.62, P=0.018$ ) and the log- additive model (crude OR = $1.24,95 \% \mathrm{Cl}: 1.01-1.52), P=0.042$; adjust $\mathrm{OR}=1.24,95 \% \mathrm{Cl}: 1.01-1.52, P=0.042)$. Rs 2243267 was found play a harmful role with the HNC risk both before and after adjusted with age and gender based on the codominant model (crude OR $=2.12,95 \% \mathrm{Cl}: 1.18-3.81, P=$ 0.012 ; adjust $\mathrm{OR}=2.12,95 \% \mathrm{Cl}: 1.18-3.81, P=0.012$ ) and the recessive model (crude OR $=2.09,95 \% \mathrm{Cl}$ : $1.17-3.73, P=0.013$; adjust OR $=2.09,95 \% \mathrm{Cl}: 1.17-3.73, P=0.013)$. Rs2243270 was also found to be significantly associated with an increased the risk of HNC both before and after adjusted with age and gender under the codominant model (crude OR = 2.06, 95\% Cl: 1.14 - 3.71, $P=0.016$; adjust OR = 2.06, 95\% Cl: $1.14-3.71, P=0.016$ ) and the recessive model (crude OR = 2.02, 95\% Cl: $1.13-3.62, P=0.018$; adjust OR = 2.02, 95\% Cl: $1.13-3.62, P=0.018)$. The three other SNPs (rs2227284, rs2243283 and rs2243289) were not found to be associated with HNC risk under the four genetic models $(P>0.05)$.

\section{Stratification analysis of IL-4 polymorphisms and HNC risk}

To further explore the gender influence on the potential HNC susceptibility of selected polymorphisms in IL-4 gene, we performed the same statistical analysis in males and females, separately (Table 5). We found that rs2243250 was associated with an increased risk of HNC in male under codominant model $(\mathrm{OR}=6.66,95 \% \mathrm{Cl}: 1.44-30.87, P=0.015)$, recessive model $(\mathrm{OR}=6.06,95 \% \mathrm{Cl}: 1.32-27.88, P=$ $0.021)$, log-additive model (OR $=1.52,95 \% \mathrm{Cl}: 1.07-2.17, P=0.020)$ and allele model $(\mathrm{OR}=1.46,95 \% \mathrm{Cl}: 1.04-2.03, P=0.027)$.

Rs2243267 was observed to be associated with the increased the susceptibility of HNC in male under codominant model (OR $=6.99,95 \%$ Cl: 1.52 - 32.06, $P=0.012)$, recessive model (OR = 6.68, 95\% Cl: $1.47-30.42, P=0.014)$ and log-additive model (OR = 1.42, $95 \% \mathrm{Cl}$ : 1.00 $2.01, P=0.049)$. Rs2243270 was significantly associated with increasing the HNC risk among male in codominant model (OR $=6.99,95 \%$ Cl: 1.52 - 32.06, $P=0.012)$, recessive model (OR = 6.68, 95\% Cl: $1.47-30.42, P=0.014)$ and log-additive model (OR = 1.42, $95 \% \mathrm{Cl}$ : 1.00 $2.01, P=0.049)$. Rs2243289 also related to increase the risk of $\mathrm{HNC}$ among male in codominant model $(\mathrm{OR}=6.25,95 \% \mathrm{Cl}: 1.35-28.96, P$ $=0.019)$ and recessive model $(\mathrm{OR}=6.09,95 \% \mathrm{Cl}: 1.32-28.00, P=0.020)$. On the contrary, the rs2243283 in $I L-4$ showed a decreased risk to the HNC susceptibility among male in recessive model $(\mathrm{OR}=0.27,95 \% \mathrm{Cl}$ : $0.07-0.98, P=0.046)$. In addition, we have not found any association between six SNPs in IL-4 gene and the risk of HNC in females.

Stages stratification analysis showed that only rs2243283 was associated with an increased risk of HNC under codominant model (OR = 2.64, 95\% Cl: $1.14-6.13, P=0.023)$, dominant model (OR = 2.78, 95\% Cl: $1.22-6.37, P=0.016)$, log-additive model (OR = 2.07, 95\% Cl: $1.27-5.90, P=0.010)$ and allele model $(\mathrm{OR}=2.07,95 \% \mathrm{Cl}: 1.10-3.89, P=0.022)($ Table 6$)$.

\section{LD and haplotype analysis}

One haplotype block including five SNPs (rs2243250, rs2227284, rs2243267, rs2243270 and rs2243283) with D' = 1 was detected in IL-4 SNPs by haplotype analyses, as shown in Figure 1. Haplotypes with frequencies equaling to $1 \%$ were selected for the analysis. The five SNPs constructed four haplotypes (TTCGG, CGGAC, CTGAC, and TTCGC). The results of the association between the IL4 haplotype and the risk of HNC are listed in Table 7. The haplotype CTGAC was significantly associated with decreased risk of HNC both before and after adjusted with age and gender (crude OR $=0.67,95 \% \mathrm{Cl}: 0.48-0.94, P=0.020$; adjust $\mathrm{OR}=0.67,95 \% \mathrm{Cl}$ : $0.47-0.94, P=0.019$ ).

\section{Discussion}

Genetic studies have provided insight into numerous diseases, including HNC. In the present study, we investigated the correlations between six SNPs in IL-4 gene and the risk of HNC. Our results indicate that the polymorphisms rs2243250, rs2243267, and rs2243270 in IL-4 gene were associated with an increased risk of HNC. Gender stratification analysis showed that in males, rs2243250, rs2243267, rs2243270 and rs2243289 were associated with an increased risk of HNC, while rs2243283 was associated with a decreased risk of HNC in males. Haplotype analysis revealed that the haplotype CTGAC was significantly associated with a decreased risk of HNC. These results suggest that polymorphisms of $I L-4$ gene may play an important role in the risk of HNC in the Chinese Han population.

Page 4/16 
The $I L-4$ gene has been mapped ton the long arm of chromosome 5 within a cluster of other cytokine genes in human beings. Meanwhile, IL-4 gene variants may affect the occurrence of cancer by change promoter activity of $I L-4$ gene and conformation of $I L-4 R$ protein directly or indirectly $[20,26]$. Based on the biological function of $I L-4$ polymorphism, numerous epidemiologic studies have been carried out to examine the effect of IL-4 gene polymorphisms on cancer risk. Currently, the relationship between IL-4 polymorphism and cancer susceptibility has been studied in gastric cancer [27], colorectal cancer [28], bladder cancer [29], lung Cancer [30], Breast cancer [31] etc.

In the present study, we investigated six SNPs in IL-4, including rs2243250, rs2227284, rs2243267, rs2243270, rs2243283 and rs2243289. Among these SNPs, rs2243267 and rs2243270 were identified that have associations with Aspirin-intolerant (AIA) [32] and renal cell carcinoma risk in males [33], rs2243283 was found to be associated with an increased risk of steroid-induced ONFH [34]. Rs2243289 was associated with steroid-induced ONFH [34] and renal cell carcinoma risk in males [33]. Rs2227284 conferred a protective effect on the lung cancer [35], asthma and allergic rhinitis [36], while associated with a small increase in prostate cancer risk [37]. Besides, many studies showed that rs2243250 were also associated with genetic susceptibility to many other diseases, such as colorectal cancer [38] $\mathbb{Z}$ lung cancer [35], gastric cancer [33]囚prostate cancer [37], renal cell carcinoma [33]凶steroid-induced osteonecrosis of the femoral head [34], asthma [39], rheumatoid arthritis and multiple sclerosis [40]. However, little information is available about the polymorphic sites in $I L-4$ and HNC susceptibility. In our study, we found that rs2243250, rs2243267 and rs2243267 were significantly associated with an increased risk of HNC. Rosenwasser et al. [41] report that T allele of IL-4 rs2243250 (C/T) polymorphism can increase gene transcription of IL-4 and thereby increases $/ L-4$ gene expression. One may speculate that this mechanism may be related to our results, suggesting that carriers of the T allele were associated with an increased risk of HNC. However, it has also been reported that IL-4-590 C>T (rs2243250) polymorphisms did not influence the development of HNC, which was contrary to our findings [42]. Therefore, the correlation between IL-4$590 \mathrm{C}>\mathrm{T}$ (rs2243250) polymorphisms and HNC risk needs to be further verified in a larger number of samples.

However, there were still some deficiencies in this study. Firstly, some bias in population selection should not be ignored. Firstly, all participants were recruited from the same hospital, so inherent selection and information bias was the unavoidable problems. Secondly, the number of cases in our study was not large enough to rule out false negative results. So, larger sample size and further confirmation in other ethnic populations are needed for further verification. Thirdly, our current research is fundamental, and further functional studies are required in order to understand the genetic factors underlying HNC.

\section{Conclusions}

To sum up, our data indicated that polymorphisms (rs2243250, rs2243267, rs2243289 and rs2243270) in IL-4 gene were significantly associated with the risk of HNC in the Chinese Han population. The results provide evidence that IL-4 polymorphisms may be genetic determinant of HNC susceptibility. Our study may provide new data to facilitate earlier diagnosis and promote early prevention of HNC, and shed light on the new candidate genes and new ideas for HNC research.

\section{Abbreviations}

HNC: Head and neck cancer; IL-4: Interleukin 4; SNPs: single nucleotide polymorphisms; OR: Odds ratio; Cls: 95\% confidence intervals.

\section{Declarations}

\section{Ethics approval and consent to participate}

The study was conducted in accordance with the Declaration of Helsinki and was approved by the ethical committee of the Hospital of the First Affiliated Hospital of Xi'an Jiaotong University, China. Written informed consent was obtained from all individual participants included in the study.

\section{Consent for publication}

Written informed consent was obtained from the patient for publication of this report.

\section{Availability of data and materials}

The datasets used or analyzed during the current study are available from the corresponding author on reasonable request.

\section{Competing interests}


The authors declare that they have no competing interests.

Funding

This study was supported by China Postdoctoral Science Foundation (No. 2015M572574).

Authors' contributions

HJL: analyzed the data. ND: performed the experiments. QZ: contributed reagents/materials/analysis tools. YS: conceived and designed the experiments. All authors contributed significantly to the final draft of the paper and agreed to submit the manuscript for publication.

\section{Acknowledgments}

We thank all patients and controls for their participation in this study. We also thank the clinicians and hospital staff who contributed to the sample and data collection.

\section{References}

1. Bose P, Brockton NT, Dort JC: Head and neck cancer: from anatomy to biology. International journal of cancer 2013, 133(9):20132023.

2. Leemans CR, Snijders PJF, Brakenhoff RH: The molecular landscape of head and neck cancer. Nature reviews Cancer 2018, 18(5):269-282.

3. Shield KD, Ferlay J, Jemal A, Sankaranarayanan R, Chaturvedi AK, Bray F, Soerjomataram I: The global incidence of lip, oral cavity, and pharyngeal cancers by subsite in 2012. CA: a cancer journal for clinicians 2017, 67(1):51-64.

4. Cohen N, Fedewa S, Chen AY: Epidemiology and Demographics of the Head and Neck Cancer Population. Oral and maxillofacial surgery clinics of North America 2018, 30(4):381-395.

5. Hopkins J, Cescon DW, Tse D, Bradbury P, Xu W, Ma C, Wheatley-Price P, Waldron J, Goldstein D, Meyer F et al: Genetic polymorphisms and head and neck cancer outcomes: a review. Cancer epidemiology, biomarkers \& prevention : a publication of the American Association for Cancer Research, cosponsored by the American Society of Preventive Oncology 2008, 17(3):490-499.

6. Jackson JR, Seed MP, Kircher CH, Willoughby DA, Winkler JD: The codependence of angiogenesis and chronic inflammation. FASEB journal : official publication of the Federation of American Societies for Experimental Biology 1997, 11(6):457-465.

7. Phoa N, Epe B: Influence of nitric oxide on the generation and repair of oxidative DNA damage in mammalian cells. Carcinogenesis 2002, 23(3):469-475.

8. Moore MA: Cytokine and chemokine networks influencing stem cell proliferation, differentiation, and marrow homing. Journal of cellular biochemistry Supplement 2002, 38:29-38.

9. Gaur P, Mittal M, Mohanti B, Das S: Functional variants of IL4 and IL6 genes and risk of tobacco-related oral carcinoma in high-risk Asian Indians. Oral diseases 2011, 17(7):720-726.

10. Toi M, Bicknell R, Harris AL: Inhibition of colon and breast carcinoma cell growth by interleukin-4. Cancer research 1992, 52(2):275279.

11. Olver S, Apte S, Baz A, Kienzle N: The duplicitous effects of interleukin 4 on tumour immunity: how can the same cytokine improve or impair control of tumour growth? Tissue antigens 2007, 69(4):293-298.

12. Li Z, Jiang J, Wang Z, Zhang J, Xiao M, Wang C, Lu Y, Qin Z: Endogenous interleukin-4 promotes tumor development by increasing tumor cell resistance to apoptosis. Cancer research 2008, 68(21):8687-8694.

13. Gocheva V, Wang HW, Gadea BB, Shree T, Hunter KE, Garfall AL, Berman T, Joyce JA: IL-4 induces cathepsin protease activity in tumor-associated macrophages to promote cancer growth and invasion. Genes \& development 2010, 24(3):241-255.

14. Myers JN, Yasumura S, Suminami Y, Hirabayashi H, Lin W, Johnson JT, Lotze MT, Whiteside TL: Growth stimulation of human head and neck squamous cell carcinoma cell lines by interleukin 4. Clinical cancer research : an official journal of the American Association for Cancer Research 1996, 2(1):127-135.

15. Kaskas NM, Moore-Medlin T, McClure GB, Ekshyyan O, Vanchiere JA, Nathan CA: Serum biomarkers in head and neck squamous cell cancer. JAMA otolaryngology- head \& neck surgery 2014, 140(1):5-11.

16. Prokopchuk O, Liu Y, Henne-Bruns D, Kornmann M: Interleukin-4 enhances proliferation of human pancreatic cancer cells: evidence for autocrine and paracrine actions. British journal of cancer 2005, 92(5):921-928.

Page 6/16 
17. Todaro M, Lombardo Y, Francipane MG, Alea MP, Cammareri P, lovino F, Di Stefano AB, Di Bernardo C, Agrusa A, Condorelli G et al: Apoptosis resistance in epithelial tumors is mediated by tumor-cell-derived interleukin-4. Cell death and differentiation 2008, 15(4):762-772.

18. Kawakami K, Leland P, Puri RK: Structure, function, and targeting of interleukin 4 receptors on human head and neck cancer cells. Cancer research 2000, 60(11):2981-2987.

19. Li S, Jin T, Zhang J, Lou H, Yang B, Li Y, Chen C, Zhang Y: Polymorphisms of TREH, IL4R and CCDC26 genes associated with risk of glioma. Cancer epidemiology 2012, 36(3):283-287.

20. Strome SE, Kawakami K, Alejandro D, Voss S, Kasperbauer JL, Salomao D, Chen L, Maki RA, Puri RK: Interleukin 4 receptor-directed cytotoxin therapy for human head and neck squamous cell carcinoma in animal models. Clinical cancer research : an official journal of the American Association for Cancer Research 2002, 8(1):281-286.

21. Serefoglou Z, Yapijakis C, Nkenke E, Vairaktaris E: Genetic association of cytokine DNA polymorphisms with head and neck cancer. Oral oncology 2008, 44(12):1093-1099.

22. Tsai MH, Chen WC, Tsai CH, Hang LW, Tsai FJ: Interleukin-4 gene, but not the interleukin-1 beta gene polymorphism, is associated with oral cancer. Journal of clinical laboratory analysis 2005, 19(3):93-98.

23. Sole X, Guino E, Valls J, Iniesta R, Moreno V: SNPStats: a web tool for the analysis of association studies. Bioinformatics (Oxford, England) 2006, 22(15):1928-1929.

24. Jin TB, Du S, Zhu XK, Li G, Ouyang Y, He N, Zhang Z, Zhang Y, Kang L, Yuan D: Polymorphism in the IL4R gene and clinical features are associated with glioma prognosis: Analyses of case-cohort studies. Medicine 2016, 95(31):e4231.

25. Yuan LJ, Jin TB, Yin JK, Du XL, Wang Q, Dong R, Wang SZ, Cui Y, Chen C, Lu JG: Polymorphisms of tumor-related genes IL-10, PSCA, MTRR and NOC3L are associated with the risk of gastric cancer in the Chinese Han population. Cancer epidemiology 2012, 36(6):e366-372.

26. Banuelos J, Lu NZ: A gradient of glucocorticoid sensitivity among helper T cell cytokines. Cytokine \& growth factor reviews 2016, 31:27-35.

27. Wang T, Tian L, Gao M, Song H, Wei Y, Xue Y: Interleukin (IL)-4 -590C>T polymorphism is not associated with the susceptibility of gastric cancer. An updated meta-analysis. Annals of medicine and surgery (2012) 2016, 9:1-5.

28. Li Q, Wang Q, Xu X, Ren S, Wang L: Association between IL-4 -589C>T polymorphism and colorectal cancer risk. Tumour biology : the journal of the International Society for Oncodevelopmental Biology and Medicine 2014, 35(3):2675-2679.

29. Bozdogan ST, Erol B, Dursun A, Bozdogan G, Donmez I, Mungan NA, Seydaoglu G: The IL-1RN and IL-4 gene polymorphisms are potential genetic markers of susceptibility to bladder cancer: a case-control study. World journal of urology 2015, 33(3):389-395.

30. Chang WS, Wang SC, Chuang CL, Ji HX, Hsiao CL, Hsu CM, Tsai CW, Liu SP, Hsu PC, Lo YL et al: Contribution of Interleukin-4 Genotypes to Lung Cancer Risk in Taiwan. Anticancer research 2015, 35(11):6297-6301.

31. Konwar R, Chaudhary P, Kumar S, Mishra D, Chattopadhyay N, Bid HK: Breast cancer risk associated with polymorphisms of IL-1RN and IL-4 gene in Indian women. Oncology research 2009, 17(8):367-372.

32. Kim BS, Park SM, Uhm TG, Kang JH, Park JS, Jang AS, Uh ST, Kim MK, Choi IS, Cho SH et al: Effect of single nucleotide polymorphisms within the interleukin-4 promoter on aspirin intolerance in asthmatics and interleukin-4 promoter activity Pharmacogenetics and genomics 2010, 20(12):748-758.

33. Rong H, He X, Wang L, He Y, Kang L, Jin T: Associations between polymorphisms in the IL-4 gene and renal cell carcinoma in Chinese Han population. Oncotarget 2017, 8(47):82078-82084.

34. Jin T, Zhang Y, Sun Y, Wu J, Xiong Z, Yang Z: IL-4 gene polymorphisms and their relation to steroid-induced osteonecrosis of the femoral head in Chinese population. Molecular genetics \& genomic medicine 2019, 7(3):e563.

35. Tan N, Song J, Yan M, Wu J, Sun Y, Xiong Z, Ding Y: Association between IL-4 tagging single nucleotide polymorphisms and the risk of lung cancer in China. Molecular genetics \& genomic medicine 2019, 7(4):e00585.

36. Micheal S, Minhas K, Ishaque M, Ahmed F, Ahmed A: IL-4 gene polymorphisms and their association with atopic asthma and allergic rhinitis in Pakistani patients. Journal of investigational allergology \& clinical immunology 2013, 23(2):107-111.

37. Tindall EA, Severi G, Hoang HN, Ma CS, Fernandez P, Southey MC, English DR, Hopper JL, Heyns CF, Tangye SG et al: Comprehensive analysis of the cytokine-rich chromosome $5 \mathrm{q} 31.1$ region suggests a role for IL-4 gene variants in prostate cancer risk. Carcinogenesis 2010, 31(10):1748-1754.

38. Shamoun L, Skarstedt M, Andersson RE, Wagsater D, Dimberg J: Association study on IL-4, IL-4Ralpha and IL-13 genetic polymorphisms in Swedish patients with colorectal cancer. Clinica chimica acta; international journal of clinical chemistry 2018 , 
487:101-106.

39. Liu S, Li T, Liu J: Interleukin-4 rs2243250 polymorphism is associated with asthma among Caucasians and related to atopic asthma. Cytokine 2012, 59(2):364-369.

40. Qiu LJ, Ni J, Cen H, Wen PF, Zhang M, Liang Y, Pan HF, Mao C, Ye DQ: Relationship between the IL-4 gene promoter -590C/T (rs2243250) polymorphism and susceptibility to autoimmune diseases: a meta-analysis. Journal of the European Academy of Dermatology and Venereology : JEADV 2015, 29(1):48-55.

41. Rosenwasser LJ, Klemm DJ, Dresback JK, Inamura H, Mascali JJ, Klinnert M, Borish L: Promoter polymorphisms in the chromosome 5 gene cluster in asthma and atopy. Clinical and experimental allergy : journal of the British Society for Allergy and Clinical Immunology 1995, 25 Suppl 2:74-78; discussion 95-76.

42. Xiao TT, Li X, Xu Y, Li Y: Significant association of the cytokine variants with head and neck cancer risk: evidence from meta-analysis. European archives of oto-rhino-laryngology : official journal of the European Federation of Oto-Rhino-Laryngological Societies (EUFOS) : affiliated with the German Society for Oto-Rhino-Laryngology - Head and Neck Surgery 2018, 275(2):483-496.

\section{Tables}

Table 1 Primers used for this study

\begin{tabular}{ccccc}
\hline SNP_ID & 2nd - PCRP & 1st - PCRP & UEP & DIR \\
\hline rs2243283 & ACGTTGGATGTGCTGACAGATCGGTTGTAG & ACGTTGGATGAAACAGTACTGACCATCGCC & F & tGGGGAGGAAAAGATGAC \\
\hline rs2243270 & ACGTTGGATGACATTCACTCATCCCACCAG & ACGTTGGATGCAGTATCAACAGTTGACCCC & R & CACCAGCCAGAGGTAACTA \\
\hline rs2243250 & ACGTTGGATGTGATACGACCTGTCCTTCTC & ACGTTGGATGTAACAGGCAGACTCTCCTAC & F & TAAACTTGGGAGAACATTGT \\
\hline rs2243267 & ACGTTGGATGAGAAACGCATTGCACAGTGG & ACGTTGGATGTATAGTTTACTCACTGCCGC & R & cccaCTATCGTGGCAGATTTTTG \\
\hline rs2243289 & ACGTTGGATGTCACAGGACAGGAATTCTGC & ACGTTGGATGGGCTTGATCAAGTAGACAGG & R & tatCTTGCATTGGTAAGCATTTGTC \\
rs2227284 & ACGTTGGATGCATTATGGAACTCTCTGTAG & ACGTTGGATGGATGAAGGGTTTCTTGGGTG & R & AGCTCTCTTTGGTAAATAGGAAAT \\
\hline
\end{tabular}

PCR: polymerase chain reaction, UEP: unextended mini-sequencing primer.

Table 2 Distributions of age and gender in HNC cases and healthy controls

\begin{tabular}{cccccc}
\hline Variable & Classification & Cases & Control & Unavailable & $P$-value \\
\hline Total & & 535 & 538 & & \\
Age & $>46$ & $296(55 \%)$ & $301(56 \%)$ & 0 & $0.257^{\mathrm{a}}$ \\
\hline & $\leq 46$ & $239(45 \%)$ & $237(44 \%)$ & 0 & $0.314^{\mathrm{a}}$ \\
\hline Gender & Age (mean \pm SD) & $46.80 \pm 15.08$ & $46.94 \pm 13.79$ & & $0.875^{\mathrm{a}}$ \\
\hline & male & $205(38 \%)$ & $208(39 \%)$ & 0 & $0.760^{b}$ \\
\hline Lymph nodes metastasis & female & $330(62 \%)$ & $330(61 \%)$ & 0 & $0.663^{b}$ \\
\hline Stage & YES vs NO & $101(19 \%)$ & $82(15 \%)$ & 27 & $0.001^{\mathrm{a}}$ \\
\hline Nasopharyngeal carcinoma & YES vs NO & $75(14 \%)$ & $538(100 \%)$ & 0 & $0.001^{\mathrm{a}}$ \\
\hline Thyroid cancer & YES vs NO & $398(74 \%)$ & $538(100 \%)$ & 0 & $0.016^{\mathrm{a}}$ \\
\hline Laryngeal cancer & YES vs NO & $43(8 \%)$ & $538(101 \%)$ & 0 & --- \\
\hline Parotid gland carcinoma & YES vs NO & $19(4 \%)$ & $538(102 \%)$ & 0 & --- \\
\hline BMI index & $\leq 46$ & --- & $242(45 \%)$ & 678 & -- \\
\cline { 2 - 6 } & $>46$ & & $153(28 \%)$ & & --- \\
\hline Smoking & --- & $92(17 \%)$ & $340(63 \%)$ & 641 & --- \\
\hline Drinking & --- & $49(9 \%)$ & $331(62 \%)$ & 693 & -- \\
\hline
\end{tabular}

$P^{\mathrm{a}}$-value obtained from Pearson's $\chi^{2}$ test; 
$P^{b}$-value obtained from independent sample $t$-test.

Table 3 Basic information and allele frequency of the selected SNPs in $I L$-4gene

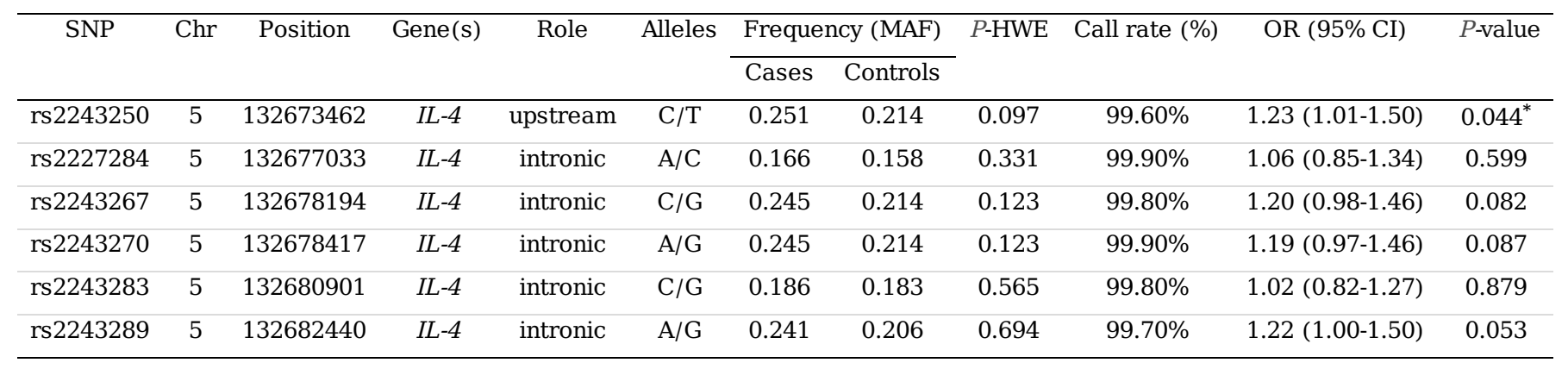

SNP: Single nucleotide polymorphism; HWE: Hardy-Weinberg equilibrium; OR: Odds ratio; 95\% CI: 95\% confidence interval;

P-HWE obtained from Fisher's exact test;

$P$-value obtained from Wald test

Table 4 Significant genetic variants in $I L 4$ gene associated with the susceptibility of HNC in Chinese Han population 


\begin{tabular}{|c|c|c|c|c|c|c|c|c|}
\hline \multirow[t]{2}{*}{ SNP } & \multirow[t]{2}{*}{ Model } & \multirow[t]{2}{*}{ Genotype } & \multirow[t]{2}{*}{ Control } & \multirow[t]{2}{*}{ Case } & \multicolumn{2}{|c|}{ Without Adjustment } & \multicolumn{2}{|c|}{ With Adjustment } \\
\hline & & & & & OR (95\% CI) & $P^{\mathrm{a}}$-value & OR (95\% CI) & $P^{\mathrm{b}}$-value \\
\hline \multirow[t]{8}{*}{ rs2243250 } & Codominant & $\mathrm{T} / \mathrm{T}$ & $325(60.5 \%)$ & $301(56.4 \%)$ & 1.00 & & 1.00 & \\
\hline & & $\mathrm{T} / \mathrm{C}$ & 194 (36.1\%) & 198 (37.1\%) & $1.10(0.86-1.42)$ & 0.451 & $1.10(0.86-1.42)$ & 0.448 \\
\hline & & $\mathrm{C} / \mathrm{C}$ & $18(3.4 \%)$ & $35(6.6 \%)$ & $2.10(1.16-3.79)$ & $0.014^{*}$ & $2.10(1.16-3.79)$ & $0.014^{*}$ \\
\hline & Dominant & $\mathrm{T} / \mathrm{T}$ & 325 (60.5\%) & 301 (56.4\%) & 1.00 & & 1.00 & \\
\hline & & $\mathrm{T} / \mathrm{C}-\mathrm{C} / \mathrm{C}$ & 212 (39.5\%) & $233(43.6 \%)$ & $1.19(0.93-1.51)$ & 0.168 & $1.19(0.93-1.52)$ & 0.167 \\
\hline & Recessive & $\mathrm{T} / \mathrm{T}-\mathrm{T} / \mathrm{C}$ & 519 (96.6\%) & 499 (3.4\%) & 1.00 & & 1.00 & \\
\hline & & $\mathrm{C} / \mathrm{C}$ & $18(3.4 \%)$ & $35(6.6 \%)$ & $2.02(1.13-3.62)$ & $0.018^{*}$ & $2.02(1.13-3.62)$ & $0.018^{*}$ \\
\hline & Log-additive & --- & --- & --- & $1.24(1.01-1.52)$ & $0.042^{*}$ & $1.24(1.01-1.52)$ & $0.042^{*}$ \\
\hline \multirow[t]{8}{*}{ rs2227284 } & Co-dominant & $\mathrm{T} / \mathrm{T}$ & 378 (70.3\%) & 377 (70.5\%) & 1.00 & & 1.00 & \\
\hline & & $\mathrm{T} / \mathrm{G}$ & 150 (27.9\%) & $138(25.8 \%)$ & $0.92(0.70-1.21)$ & 0.56 & $0.92(0.70-1.21)$ & 0.560 \\
\hline & & $\mathrm{G} / \mathrm{G}$ & $10(1.9 \%)$ & $20(3.7 \%)$ & $2.01(0.93-4.34)$ & 0.077 & $2.00(0.92-4.35)$ & 0.079 \\
\hline & Dominant & $\mathrm{T} / \mathrm{T}$ & 378 (70.3\%) & 377 (70.5\%) & 1.00 & & 1.00 & \\
\hline & & $\mathrm{T} / \mathrm{G}-\mathrm{G} / \mathrm{G}$ & $160(29.7 \%)$ & 158 (29.5\%) & $0.99(0.76-1.29)$ & 0.941 & $0.99(0.76-1.29)$ & 0.938 \\
\hline & Recessive & $\mathrm{T} / \mathrm{T}-\mathrm{T} / \mathrm{G}$ & 528 (98.1\%) & 515 (96.3\%) & 1.00 & & 1.00 & \\
\hline & & $\mathrm{G} / \mathrm{G}$ & $10(1.9 \%)$ & $20(3.7 \%)$ & $2.05(0.95-4.42)$ & 0.067 & $2.05(0.95-4.43)$ & 0.068 \\
\hline & Log-additive & --- & --- & --- & $1.06(0.85-1.34)$ & 0.602 & $1.06(0.85-1.33)$ & 0.607 \\
\hline \multirow[t]{8}{*}{ rs2243267 } & Co-dominant & $\mathrm{C} / \mathrm{C}$ & $326(60.6 \%)$ & 308 (57.7\%) & 1.00 & & 1.00 & \\
\hline & & $\mathrm{G} / \mathrm{C}$ & $194(36.1 \%)$ & $190(35.6 \%)$ & $1.04(0.80-1.34)$ & 0.781 & $1.04(0.80-1.34)$ & 0.778 \\
\hline & & $\mathrm{G} / \mathrm{G}$ & $18(3.3 \%)$ & $36(6.7 \%)$ & $2.12(1.18-3.81)$ & $0.012^{*}$ & $2.12(1.18-3.81)$ & $0.012^{*}$ \\
\hline & Dominant & $\mathrm{C} / \mathrm{C}$ & $326(60.6 \%)$ & 308 (57.7\%) & 1.00 & & 1.00 & \\
\hline & & $\mathrm{C} / \mathrm{G}-\mathrm{G} / \mathrm{G}$ & 212 (39.4\%) & 226 (42.3\%) & $1.13(0.88-1.44)$ & 0.331 & $1.13(0.88-1.44)$ & 0.33 \\
\hline & Recessive & $\mathrm{C} / \mathrm{C}-\mathrm{G} / \mathrm{C}$ & $520(96.7 \%)$ & 498 (93.3\%) & 1.00 & & 1.00 & \\
\hline & & $\mathrm{G} / \mathrm{G}$ & $18(3.3 \%)$ & $36(6.7 \%)$ & 2.09 (1.17-3.73) & $0.013^{*}$ & $2.09(1.17-3.73)$ & $0.013^{*}$ \\
\hline & Log-additive & --- & --- & --- & $1.2(0.98-1.47)$ & 0.081 & $1.2(0.98-1.47)$ & 0.081 \\
\hline \multirow[t]{8}{*}{ rs2243270 } & Co-dominant & $\mathrm{G} / \mathrm{G}$ & $326(60.6 \%)$ & 308 (57.6\%) & 1.00 & & 1.00 & \\
\hline & & $\mathrm{G} / \mathrm{A}$ & $194(36.1 \%)$ & $192(35.9 \%)$ & $1.05(0.81-1.35)$ & 0.719 & $1.05(0.81-1.35)$ & 0.717 \\
\hline & & $\mathrm{A} / \mathrm{A}$ & $18(3.3 \%)$ & $35(6.5 \%)$ & $2.06(1.14-3.71)$ & $0.016^{*}$ & $2.06(1.14-3.71)$ & $0.017^{*}$ \\
\hline & Dominant & $\mathrm{G} / \mathrm{G}$ & $326(60.6 \%)$ & 308 (57.6\%) & 1.00 & & 1.00 & \\
\hline & & G/A-A/A & $212(39.4 \%)$ & 227 (42.4\%) & $1.13(0.89-1.45)$ & 0.314 & $1.13(0.89-1.45)$ & 0.313 \\
\hline & Recessive & G/G-G/T & 520 (96.7\%) & 500 (93.5\%) & 1.00 & & 1.00 & \\
\hline & & $\mathrm{A} / \mathrm{A}$ & $18(3.3 \%)$ & $35(6.5 \%)$ & $2.02(1.13-3.62)$ & $0.018^{*}$ & $2.02(1.13-3.62)$ & $0.018^{*}$ \\
\hline & Log-additive & --- & --- & --- & $1.2(0.98-1.47)$ & 0.084 & $1.2(0.98-1.47)$ & 0.084 \\
\hline \multirow[t]{8}{*}{ rs2243283 } & Co-dominant & $\mathrm{C} / \mathrm{C}$ & $360(67.0 \%)$ & 350 (65.4\%) & 1.00 & & 1.00 & \\
\hline & & $\mathrm{G} / \mathrm{C}$ & $157(29.2 \%)$ & $171(32.0 \%)$ & $1.12(0.86-1.46)$ & 0.395 & $1.12(0.86-1.46)$ & 0.398 \\
\hline & & $\mathrm{G} / \mathrm{G}$ & $20(3.7 \%)$ & $14(2.6 \%)$ & $0.72(0.36-1.45)$ & 0.357 & $0.72(0.36-1.45)$ & 0.355 \\
\hline & Dominant & $\mathrm{C} / \mathrm{C}$ & $360(67.0 \%)$ & 350 (65.4\%) & 1.00 & & 1.00 & \\
\hline & & C/G-G/G & 177 (33.0\%) & $185(34.6 \%)$ & $1.08(0.83-1.39)$ & 0.575 & $1.08(0.83-1.39)$ & 0.578 \\
\hline & Recessive & $\mathrm{C} / \mathrm{C}-\mathrm{G} / \mathrm{C}$ & 517 (96.3\%) & 521 (97.4\%) & 1.00 & & 1.00 & \\
\hline & & $\mathrm{G} / \mathrm{G}$ & $20(3.7 \%)$ & $14(2.6 \%)$ & 0.69 (0.35-1.39) & 0.303 & $0.69(0.35-1.39)$ & 0.302 \\
\hline & Log-additive & --- & --- & --- & $1.02(0.82-1.27)$ & 0.878 & $1.02(0.82-1.27)$ & 0.882 \\
\hline \multirow[t]{8}{*}{ rs2243289 } & Co-dominant & $\mathrm{G} / \mathrm{G}$ & 340 (63.3\%) & 311 (58.2\%) & 1.00 & & 1.00 & \\
\hline & & $\mathrm{G} / \mathrm{A}$ & $173(32.2 \%)$ & 189 (35.4\%) & $1.19(0.92-1.55)$ & 0.176 & $1.2(0.92-1.55)$ & 0.175 \\
\hline & & $\mathrm{A} / \mathrm{A}$ & $24(4.5 \%)$ & $34(6.4 \%)$ & $1.55(0.90-2.67)$ & 0.116 & $1.55(0.90-2.67)$ & 0.118 \\
\hline & Dominant & $\mathrm{G} / \mathrm{G}$ & 340 (63.3\%) & 311 (58.2\%) & 1.00 & & 1.00 & \\
\hline & & G/A-A/A & 197 (36.7\%) & 223 (41.8\%) & $1.24(0.97-1.58)$ & 0.089 & $1.24(0.97-1.58)$ & 0.089 \\
\hline & Recessive & G/G-G/T & $513(95.5 \%)$ & $500(93.6 \%)$ & 1.00 & & 1.00 & \\
\hline & & $\mathrm{A} / \mathrm{A}$ & $24(4.5 \%)$ & $34(6.4 \%)$ & $1.45(0.85-2.49)$ & 0.172 & $1.45(0.85-2.49)$ & 0.174 \\
\hline & Log-additive & --- & --- & --- & $1.22(0.99-1.49)$ & 0.056 & $1.22(0.99-1.49)$ & 0.056 \\
\hline
\end{tabular}


SNP: Single nucleotide polymorphism; OR: Odds ratio; 95\% CI: 95\% confidence interval;

$P^{\mathrm{a}}$-value calculated by logistic regression analysis;

$P^{\mathrm{b}}$-value calculated by logistic regression analysis with adjustments for gender and age;

${ }^{*} P$-value $<0.05$ indicates statistical significance.

Table 5 Stratified analysis of IL4 polymorphisms by gender and risk of HNC 


\begin{tabular}{|c|c|c|c|c|c|c|c|c|c|c|}
\hline \multirow[t]{2}{*}{ SNP } & \multirow[t]{2}{*}{ Model } & \multirow[t]{2}{*}{ Genotype } & \multicolumn{4}{|c|}{ Male } & \multicolumn{4}{|c|}{ Female } \\
\hline & & & Control & Case & OR (95\% CI) & $\begin{array}{c}P- \\
\text { value }\end{array}$ & Control & Case & OR (95\% CI) & $\begin{array}{c}P- \\
\text { value }\end{array}$ \\
\hline \multirow[t]{10}{*}{ rs2243250 } & Codominant & $\mathrm{T} / \mathrm{T}$ & $\begin{array}{c}131 \\
(63.3 \%)\end{array}$ & $\begin{array}{c}112 \\
(54.9 \%)\end{array}$ & 1.00 & & $\begin{array}{c}194 \\
(58.8 \%)\end{array}$ & $\begin{array}{c}189 \\
(57.3 \%)\end{array}$ & 1.00 & \\
\hline & & $\mathrm{T} / \mathrm{C}$ & $74(35.7 \%)$ & 81 (39.7\%) & $1.28(0.85-1.91)$ & 0.235 & $\begin{array}{c}120 \\
(36.4 \%)\end{array}$ & $\begin{array}{c}117 \\
(35.5 \%)\end{array}$ & $\begin{array}{c}1.00(0.73- \\
1.39)\end{array}$ & 0.981 \\
\hline & & $\mathrm{C} / \mathrm{C}$ & $2(1.0 \%)$ & $11(5.4 \%)$ & $\begin{array}{c}6.66(1.44- \\
30.87)\end{array}$ & $0.015^{*}$ & $16(4.8 \%)$ & $24(7.3 \%)$ & $\begin{array}{c}1.55(0.80- \\
3.00)\end{array}$ & 0.199 \\
\hline & Dominant & $\mathrm{T} / \mathrm{T}$ & $\begin{array}{c}131 \\
(63.3 \%)\end{array}$ & $\begin{array}{c}112 \\
(54.9 \%)\end{array}$ & 1.00 & & $\begin{array}{c}194 \\
(58.8 \%)\end{array}$ & $\begin{array}{c}189 \\
(57.3 \%)\end{array}$ & 1.00 & \\
\hline & & $\mathrm{T} / \mathrm{C}-\mathrm{C} / \mathrm{C}$ & $76(36.7 \%)$ & $92(45.1 \%)$ & $1.42(0.95-2.10)$ & 0.084 & $\begin{array}{c}136 \\
(41.2 \%)\end{array}$ & $\begin{array}{c}141 \\
(42.7 \%)\end{array}$ & $\begin{array}{c}1.07(0.78- \\
1.46)\end{array}$ & 0.679 \\
\hline & Recessive & $\mathrm{T} / \mathrm{T}-\mathrm{T} / \mathrm{C}$ & $\begin{array}{c}205 \\
(99.9 \%)\end{array}$ & $\begin{array}{c}193 \\
(94.6 \%)\end{array}$ & 1.00 & & $\begin{array}{c}314 \\
(95.2 \%)\end{array}$ & $\begin{array}{c}306 \\
(92.7 \%)\end{array}$ & 1.00 & \\
\hline & & $\mathrm{C} / \mathrm{C}$ & $2(1.0 \%)$ & $11(5.4 \%)$ & $\begin{array}{c}6.06(1.32- \\
27.88)\end{array}$ & $0.021^{*}$ & $16(4.8 \%)$ & $24(7.3 \%)$ & $1.54(0.8-2.96)$ & 0.193 \\
\hline & $\begin{array}{l}\text { Log- } \\
\text { additive }\end{array}$ & --- & --- & --- & $1.52(1.07-2.17)$ & $0.020^{*}$ & --- & --- & $\begin{array}{c}1.12(0.87- \\
1.43)\end{array}$ & 0.396 \\
\hline & Allele & $\mathrm{T}$ & $\begin{array}{c}336 \\
(81.2 \%)\end{array}$ & $\begin{array}{c}305 \\
(74.8 \%)\end{array}$ & 1.00 & & $\begin{array}{c}508 \\
(77.0 \%)\end{array}$ & $\begin{array}{c}495 \\
(75.0 \%)\end{array}$ & 1.00 & \\
\hline & & $\mathrm{C}$ & 78 (29.8\%) & $\begin{array}{c}103 \\
(25.2 \%)\end{array}$ & $1.46(1.04-2.03)$ & $0.027^{*}$ & $\begin{array}{c}152 \\
(23.0 \%)\end{array}$ & $\begin{array}{c}165 \\
(25.0 \%)\end{array}$ & $\begin{array}{c}1.11(0.87- \\
1.43)\end{array}$ & 0.402 \\
\hline \multirow[t]{10}{*}{ rs2227284 } & $\begin{array}{c}\text { Co- } \\
\text { dominant }\end{array}$ & $\mathrm{T} / \mathrm{T}$ & $\begin{array}{c}148 \\
(71.2 \%)\end{array}$ & $\begin{array}{c}143 \\
(69.8 \%)\end{array}$ & 1.00 & & $\begin{array}{c}230 \\
(69.7 \%)\end{array}$ & $\begin{array}{c}234 \\
(70.9 \%)\end{array}$ & 1.00 & \\
\hline & & $\mathrm{T} / \mathrm{G}$ & $58(26.9 \%)$ & $56(27.3 \%)$ & $1.00(0.65-1.54)$ & 0.996 & $92(24.8 \%)$ & $82(24.8 \%)$ & $\begin{array}{c}0.88(0.62- \\
1.24)\end{array}$ & 0.455 \\
\hline & & $\mathrm{G} / \mathrm{G}$ & $2(1.0 \%)$ & $6(2.9 \%)$ & $\begin{array}{c}3.29(0.64- \\
16.78)\end{array}$ & 0.153 & $8(2.4 \%)$ & $14(4.2 \%)$ & $1.71(0.7-4.16)$ & 0.236 \\
\hline & Dominant & $\mathrm{T} / \mathrm{T}$ & $\begin{array}{c}148 \\
(71.2 \%)\end{array}$ & $\begin{array}{c}143 \\
(69.8 \%)\end{array}$ & 1.00 & & $\begin{array}{c}230 \\
(69.7 \%)\end{array}$ & $\begin{array}{c}234 \\
(70.9 \%)\end{array}$ & 1.00 & \\
\hline & & T/G-G/G & $60(28.8 \%)$ & 62 & $1.07(0.70-1.64)$ & 0.749 & $\begin{array}{c}100 \\
(30.3 \%)\end{array}$ & 96 (39.1\%) & $\begin{array}{c}0.94(0.67- \\
1.32)\end{array}$ & 0.727 \\
\hline & Recessive & $\mathrm{T} / \mathrm{T}-\mathrm{T} / \mathrm{G}$ & $\begin{array}{c}206 \\
(99.0 \%)\end{array}$ & $\begin{array}{c}199 \\
(97.1 \%)\end{array}$ & 1.00 & & $\begin{array}{c}322 \\
(97.6 \%)\end{array}$ & $\begin{array}{c}316 \\
(95.8 \%)\end{array}$ & 1.00 & \\
\hline & & $\mathrm{G} / \mathrm{G}$ & $2(1.0 \%)$ & $6(2.9 \%)$ & $\begin{array}{c}3.29(0.65- \\
16.71)\end{array}$ & 0.152 & $8(2.4 \%)$ & $14(4.2 \%)$ & $\begin{array}{c}1.77(0.73- \\
4.29)\end{array}$ & 0.203 \\
\hline & $\begin{array}{c}\text { Log- } \\
\text { additive }\end{array}$ & --- & --- & --- & $1.15(0.78-1.68)$ & 0.485 & -- & --- & $\begin{array}{c}1.02(0.77- \\
1.36)\end{array}$ & 0.894 \\
\hline & Allele & $\mathrm{T}$ & $\begin{array}{c}354 \\
(85.1 \%)\end{array}$ & $\begin{array}{c}342 \\
(83.4 \%)\end{array}$ & 1.00 & & $\begin{array}{c}552 \\
(83.6 \%)\end{array}$ & $\begin{array}{c}550 \\
(83.3 \%)\end{array}$ & 1.00 & \\
\hline & & $\mathrm{G}$ & $62(14.9 \%)$ & $68(16.6 \%)$ & $1.14(0.78-1.65)$ & 0.507 & $\begin{array}{c}108 \\
(16.4 \%)\end{array}$ & $\begin{array}{c}110 \\
(16.7 \%)\end{array}$ & $\begin{array}{c}1.02(0.76- \\
1.37)\end{array}$ & 0.882 \\
\hline \multirow[t]{10}{*}{ rs2243267 } & $\begin{array}{c}\text { Co- } \\
\text { dominant }\end{array}$ & $\mathrm{C} / \mathrm{C}$ & $\begin{array}{c}132 \\
(63.5 \%)\end{array}$ & $\begin{array}{c}118 \\
(57.6 \%)\end{array}$ & 1.00 & & $\begin{array}{c}194 \\
(58.8 \%)\end{array}$ & $\begin{array}{c}190 \\
(57.8 \%)\end{array}$ & 1.00 & \\
\hline & & $\mathrm{G} / \mathrm{C}$ & 74 (35.6\%) & 75 (36.6\%) & $1.13(0.75-1.70)$ & 0.553 & $\begin{array}{c}120 \\
(36.4 \%)\end{array}$ & 115 (35\%) & $\begin{array}{c}0.98(0.71- \\
1.36)\end{array}$ & 0.912 \\
\hline & & $\mathrm{G} / \mathrm{G}$ & $2(1 \%)$ & 12 (5.9\%) & $\begin{array}{c}6.99(1.52- \\
32.06)\end{array}$ & $0.012^{*}$ & 16 (4.8\%) & $24(7.3 \%)$ & $\begin{array}{c}1.54(0.79- \\
2.99)\end{array}$ & 0.204 \\
\hline & Dominant & $\mathrm{C} / \mathrm{C}$ & $\begin{array}{c}132 \\
(63.5 \%)\end{array}$ & $\begin{array}{c}118 \\
(57.6 \%)\end{array}$ & 1.00 & & $\begin{array}{c}194 \\
(58.8 \%)\end{array}$ & $\begin{array}{c}190 \\
(57.8 \%)\end{array}$ & 1.00 & \\
\hline & & $\mathrm{C} / \mathrm{G}-\mathrm{G} / \mathrm{G}$ & 76 (36.5\%) & 87 (42.4\%) & $1.28(0.86-1.90)$ & 0.22 & $\begin{array}{c}136 \\
(41.2 \%)\end{array}$ & $\begin{array}{c}139 \\
(42.2 \%)\end{array}$ & $\begin{array}{c}1.05(0.77- \\
1.43)\end{array}$ & 0.771 \\
\hline & Recessive & C/C-G/C & $\begin{array}{c}206 \\
(99.0 \%)\end{array}$ & $\begin{array}{c}193 \\
(94.1 \%)\end{array}$ & 1.00 & & $\begin{array}{c}314 \\
(95.2 \%)\end{array}$ & $\begin{array}{c}305 \\
(92.7 \%)\end{array}$ & 1.00 & \\
\hline & & $\mathrm{G} / \mathrm{G}$ & $2(1.0 \%)$ & $12(5.9 \%)$ & $\begin{array}{c}\text { 6.68(1.47- } \\
30.42)\end{array}$ & $0.014^{*}$ & $16(4.8 \%)$ & $24(7.3 \%)$ & $\begin{array}{c}1.55(0.81- \\
2.97)\end{array}$ & 0.189 \\
\hline & $\begin{array}{l}\text { Log- } \\
\text { additive }\end{array}$ & --- & --- & --- & $1.42(1.00-2.01)$ & $0.049^{*}$ & -- & -- & $\begin{array}{c}1.10(0.86- \\
1.42)\end{array}$ & 0.451 \\
\hline & Allele & $\mathrm{C}$ & $\begin{array}{c}338 \\
(81.3 \%)\end{array}$ & $\begin{array}{c}311 \\
(75.9 \%)\end{array}$ & 1.00 & & $\begin{array}{c}508 \\
(77.0 \%)\end{array}$ & $\begin{array}{c}495 \\
(75.2 \%)\end{array}$ & 1.00 & \\
\hline & & $\mathrm{G}$ & 78 (18.8\%) & 99 (24.1\%) & $1.38(0.99-1.93)$ & 0.059 & $\begin{array}{c}152 \\
(23.0 \%)\end{array}$ & $\begin{array}{c}163 \\
(24.8 \%)\end{array}$ & $\begin{array}{c}1.10(0.85- \\
1.42)\end{array}$ & 0.459 \\
\hline \multirow[t]{7}{*}{ rs2243270 } & $\begin{array}{c}\text { Co- } \\
\text { dominant }\end{array}$ & $\mathrm{G} / \mathrm{G}$ & $\begin{array}{c}132 \\
(63.5 \%)\end{array}$ & $\begin{array}{c}118 \\
(57.6 \%)\end{array}$ & 1.00 & & $\begin{array}{c}194 \\
(58.8 \%)\end{array}$ & $\begin{array}{c}190 \\
(57.6 \%)\end{array}$ & 1.00 & \\
\hline & & $\mathrm{G} / \mathrm{A}$ & 74 (35.6\%) & 75 (36.6\%) & $1.13(0.75-1.70)$ & 0.553 & $\begin{array}{c}120 \\
(36.4 \%)\end{array}$ & $\begin{array}{c}117 \\
(35.5 \%)\end{array}$ & $\begin{array}{c}1.00(0.72- \\
1.38)\end{array}$ & 0.994 \\
\hline & & $\mathrm{A} / \mathrm{A}$ & $2(1.0 \%)$ & $12(5.9 \%)$ & $\begin{array}{c}6.99(1.52- \\
32.06)\end{array}$ & $0.012^{*}$ & $16(4.8 \%)$ & $23(7.0 \%)$ & $\begin{array}{c}1.47(0.75- \\
2.88)\end{array}$ & 0.256 \\
\hline & Dominant & $\mathrm{G} / \mathrm{G}$ & $\begin{array}{c}132 \\
(63.5 \%)\end{array}$ & $\begin{array}{c}118 \\
(57.6 \%)\end{array}$ & 1.00 & & $\begin{array}{c}194 \\
(58.8 \%)\end{array}$ & $\begin{array}{c}190 \\
(57.6 \%)\end{array}$ & 1.00 & \\
\hline & & G/A-A/A & $76(36.5 \%)$ & 87 (42.4\%) & $1.28(0.86-1.90)$ & 0.22 & $\begin{array}{c}136 \\
(41.2 \%)\end{array}$ & $\begin{array}{c}140 \\
(42.4 \%)\end{array}$ & $\begin{array}{c}1.06(0.77- \\
1.44)\end{array}$ & 0.737 \\
\hline & Recessive & G/G-G/T & $\begin{array}{c}206 \\
(99.0 \%)\end{array}$ & $\begin{array}{c}193 \\
(94.1 \%)\end{array}$ & 1.00 & & $\begin{array}{c}314 \\
(95.2 \%)\end{array}$ & $\begin{array}{c}307 \\
(93.0 \%)\end{array}$ & 1.00 & \\
\hline & & $\mathrm{A} / \mathrm{A}$ & $2(1.0 \%)$ & $12(5.9 \%)$ & $\begin{array}{r}\text { 6.68(1.47- } \\
\text { Page } 12 / 16\end{array}$ & $0.014^{*}$ & $16(4.8 \%)$ & $23(7.0 \%)$ & $1.47(0.76-$ & 0.247 \\
\hline
\end{tabular}


$30.42)$

2.85)

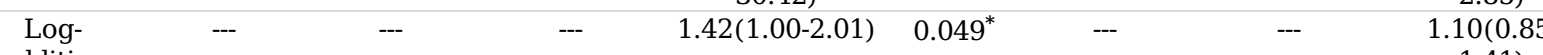

0.468

additive

Allele

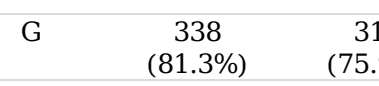

$311 \quad 1.00$

$\begin{array}{ccc} & 508 & \\ & & \\ & (77.0 \%) & (75.3 \%)\end{array}$

$1.41)$

A $\quad 78(18.8 \%) \quad 99(24.1 \%) \quad 1.38(0.99-1.93) \quad 0.059$

$(23.0 \%) \quad(24.7 \%)$

1.00

224

$(68.1 \%)$

220

dominant

$136 \quad 130$

$(63.4 \%)$

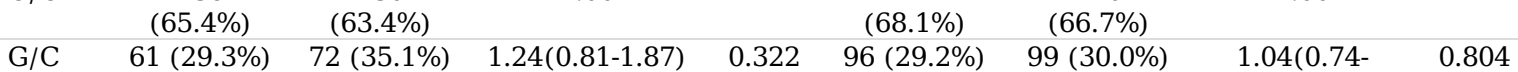

(66.7\%)

G/G $11(5.3 \%)$

$3(1.5 \%)$

$0.29(0.08-1.06) \quad 0.060 \quad 9(2.7 \%)$

$11(3.3 \%)$

1.46)

1.24(0.51- $\quad 0.634$

Dominant

$\mathrm{C} / \mathrm{C}$

$\begin{array}{cc}136 & 130 \\ (65.4 \%) & (63.4 \%)\end{array}$

1.00

224

(68.1\%)

220

3.06)

C/G-G/G $\quad 72(34.6 \%) \quad 75(36.6 \%)$

$1.09(0.73-1.63) \quad 0.671$

105

(31.9\%)

(66.7\%)

Recessive

C/C-G/C

197
$(94.7 \%)$

202
$(98.5 \%)$

1.00

320

G/G $\quad 11(5.3 \%) \quad 3(1.5 \%)$

(97.3\%)

110

$33.3 \%)$

$\begin{array}{cc}(97.3 \%) & (96.7 \% 0 \\ 9(2.7 \%) & 11(3.3 \%)\end{array}$

Log-

additive

Allele

---

$-$

$0.27(0.07-0.98) \quad 0.046^{*}$

$0.94(0.67-1.34) \quad 0.743$

---

$\begin{array}{cccc}\text { C } & 333 & 332 & 1.00 \\ & (80.0 \%) & (81.0 \%) & \\ \text { G } & 83(20.0 \%) & 78(19.0 \%) & 0.94(0.67\end{array}$

1.00

544

(82.7\%)

$--$

$--$

1.06(0.77-

0.723

1.47)

1.00

$1.23(0.50-\quad 0.653$

$3.00)$
$1.07(0.80$

0.651

$1.42)$

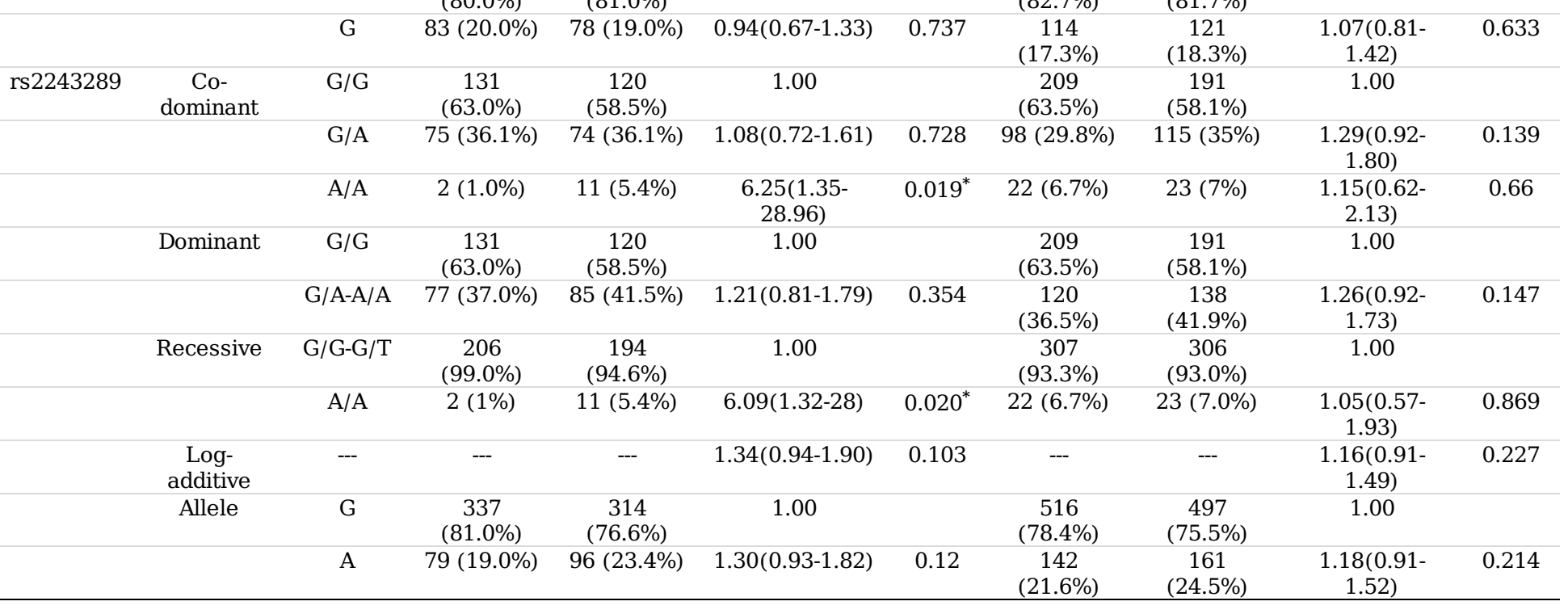

SNP: Single nucleotide polymorphism; OR: Odds ratio; 95\% CI: 95\% confidence interval;

$P$-value calculated by logistic regression analysis with adjustments for gender and age;

${ }^{*} P$-value $<0.05$ indicates statistical significance.

Table 6 Stratified analysis of IL4 polymorphisms by stages and risk of HNC 


\begin{tabular}{|c|c|c|c|c|c|c|}
\hline \multirow[t]{2}{*}{ SNP } & \multirow[t]{2}{*}{ Model } & \multirow[t]{2}{*}{ Genotype } & \multirow[t]{2}{*}{ Control } & \multirow[t]{2}{*}{ Case } & \multicolumn{2}{|c|}{ With adjustment } \\
\hline & & & & & OR(95\% CI) & $P$-value \\
\hline \multirow[t]{10}{*}{ rs2243250 } & Codominant & $\mathrm{T} / \mathrm{T}$ & $80(57.1 \%)$ & 19 (57.6\%) & 1.00 & \\
\hline & & $\mathrm{T} / \mathrm{C}$ & $54(38.6 \%)$ & $13(39.4 \%)$ & $0.77(0.33-1.80)$ & 0.544 \\
\hline & & $\mathrm{C} / \mathrm{C}$ & $6(4.3 \%)$ & $1(3 \%)$ & $0.71(0.07-7.20)$ & 0.774 \\
\hline & Dominant & $\mathrm{T} / \mathrm{T}$ & $80(57.1 \%)$ & 19 (57.6\%) & 1.00 & \\
\hline & & $\mathrm{T} / \mathrm{C}-\mathrm{C} / \mathrm{C}$ & $60(42.9 \%) \%)$ & $14(42.4 \%)$ & $0.76(0.33-1.75)$ & 0.524 \\
\hline & Recessive & $\mathrm{T} / \mathrm{T}-\mathrm{T} / \mathrm{C}$ & 134 (95.7\%) & $32(97.0 \%)$ & 1.00 & \\
\hline & & $\mathrm{C} / \mathrm{C}$ & $6(4.3 \%)$ & $1(3.0 \%)$ & $0.79(0.08-7.75)$ & 0.841 \\
\hline & Log-additive & --- & --- & --- & $0.79(0.38-1.65)$ & 0.534 \\
\hline & Allele & $\mathrm{T}$ & $214(76.4 \%)$ & $51(77.3 \%)$ & 1.00 & \\
\hline & & $\mathrm{C}$ & $66(23.6 \%)$ & $15(22.7 \%)$ & $0.95(0.50-1.81)$ & 0.884 \\
\hline \multirow{10}{*}{ rs2227284 } & Co-dominant & $\mathrm{T} / \mathrm{T}$ & 97 (69.3\%) & $23(69.7 \%)$ & 1.00 & \\
\hline & & $\mathrm{T} / \mathrm{G}$ & 39 (37.1\%) & $9(27.3 \%)$ & $0.78(0.31-1.94)$ & 0.588 \\
\hline & & $\mathrm{G} / \mathrm{G}$ & $4(3.6 \%)$ & $1(3.0 \%)$ & $1.00(0.09-11.32)$ & 0.997 \\
\hline & Dominant & $\mathrm{T} / \mathrm{T}$ & 97 (69.3\%) & $23(69.7 \%)$ & 1.00 & \\
\hline & & $\mathrm{T} / \mathrm{G}-\mathrm{G} / \mathrm{G}$ & $43(30.7 \%)$ & $10(30.3 \%)$ & $0.79(0.33-1.92)$ & 0.609 \\
\hline & Recessive & $\mathrm{T} / \mathrm{T}-\mathrm{T} / \mathrm{G}$ & 136 (96.4\%) & $32(97.0 \%)$ & 1.00 & \\
\hline & & $\mathrm{G} / \mathrm{G}$ & $4(3.6 \%)$ & $1(3.0 \%)$ & $1.07(0.10-11.96)$ & 0.955 \\
\hline & Log-additive & --- & --- & --- & $0.84(0.39-1.83)$ & 0.665 \\
\hline & Allele & $\mathrm{T}$ & $233(83.2 \%)$ & 55 (83.3\%) & 1.00 & \\
\hline & & G & 47 (16.8\%) & $11(16.7 \%)$ & $0.99(0.48-2.04)$ & 0.981 \\
\hline \multirow[t]{10}{*}{ rs2243267 } & Co-dominant & $\mathrm{C} / \mathrm{C}$ & $84(60.0 \%)$ & 19 (57.6\%) & 1.00 & \\
\hline & & $\mathrm{G} / \mathrm{C}$ & $50(35.7 \%)$ & $13(39.4 \%)$ & $0.94(0.40-2.18)$ & 0.878 \\
\hline & & $\mathrm{G} / \mathrm{G}$ & $6(4.3 \%)$ & $1(3 \%)$ & $0.77(0.08-7.75)$ & 0.826 \\
\hline & Dominant & $\mathrm{C} / \mathrm{C}$ & $84(60.0 \%)$ & 19 (57.6\%) & 1.00 & \\
\hline & & C/G-G/G & $56(40.0 \%)$ & $14(42.4 \%)$ & $0.92(0.40-2.10)$ & 0.844 \\
\hline & Recessive & $\mathrm{C} / \mathrm{C}-\mathrm{G} / \mathrm{C}$ & 134 (95.7\%) & $32(97.0 \%)$ & 1.00 & \\
\hline & & $\mathrm{G} / \mathrm{G}$ & $6(4.3 \%)$ & $1(3.0 \%)$ & $0.79(0.08-7.75)$ & 0.841 \\
\hline & Log-additive & --- & --- & --- & $0.92(0.45-1.89)$ & 0.812 \\
\hline & Allele & $\mathrm{C}$ & 218 (77.9\%) & $51(77.3 \%)$ & 1.00 & \\
\hline & & G & $62(22.1 \%)$ & 15 (22.7\%) & $1.03(0.54-1.96)$ & 0.918 \\
\hline \multirow[t]{10}{*}{ rs2243270 } & Co-dominant & $\mathrm{G} / \mathrm{G}$ & $84(60.0 \%)$ & 19 (57.6\%) & 1.00 & \\
\hline & & $\mathrm{G} / \mathrm{A}$ & $51(36.4 \%)$ & $13(39.4 \%)$ & $0.93(0.40-2.15)$ & 0.859 \\
\hline & & $\mathrm{A} / \mathrm{A}$ & $5(3.6 \%)$ & $1(3 \%)$ & $0.86(0.08-8.94)$ & 0.896 \\
\hline & Dominant & $\mathrm{G} / \mathrm{G}$ & $84(60.0 \%)$ & 19 (57.6\%) & 1.00 & \\
\hline & & G/A-A/A & $56(40.0 \%)$ & $14(42.4 \%)$ & $0.92(0.40-2.10)$ & 0.844 \\
\hline & Recessive & G/G-G/T & 135 (96.4\%) & $32(97.0 \%)$ & 1.00 & \\
\hline & & $\mathrm{A} / \mathrm{A}$ & $5(3.6 \%)$ & $1(3.0 \%)$ & $0.88(0.09-8.98)$ & 0.915 \\
\hline & Log-additive & --- & --- & --- & $0.93(0.45-1.92)$ & 0.836 \\
\hline & Allele & G & $219(78.2 \%)$ & $51(77.3 \%)$ & 1.00 & \\
\hline & & A & $61(21.8 \%)$ & 15 (22.7\%) & $1.06(0.56-2.01)$ & 0.868 \\
\hline \multirow[t]{8}{*}{ rs2243283 } & Co-dominant & $\mathrm{C} / \mathrm{C}$ & $98(70.0 \%)$ & 16 (48.5\%) & 1.00 & \\
\hline & & $\mathrm{G} / \mathrm{C}$ & $41(29.3 \%)$ & $16(48.5 \%)$ & $2.64(1.14-6.13)$ & $0.023^{*}$ \\
\hline & & $\mathrm{G} / \mathrm{G}$ & $1(0.7 \%)$ & $1(3.0 \%)$ & $9.57(0.51-179.7)$ & 0.131 \\
\hline & Dominant & $\mathrm{C} / \mathrm{C}$ & $98(70 \%)$ & 16 (48.5\%) & 1.00 & \\
\hline & & $\mathrm{C} / \mathrm{G}-\mathrm{G} / \mathrm{G}$ & $42(30.0 \%)$ & 17 (51.5\%) & $2.78(1.22-6.37)$ & $0.016^{*}$ \\
\hline & Recessive & $\mathrm{C} / \mathrm{C}-\mathrm{G} / \mathrm{C}$ & 139 (99.3\%) & 32 (97.0\%) & 1.00 & \\
\hline & & $\mathrm{G} / \mathrm{G}$ & $1(0.7 \%)$ & $1(3.0 \%)$ & $6.57(0.36-120)$ & 0.204 \\
\hline & Log-additive & --- & --- & --- & $2.73(1.27-5.90)$ & $0.010^{*}$ \\
\hline
\end{tabular}




\begin{tabular}{ccccccc} 
& Allele & $\mathrm{C}$ & $237(84.6 \%)$ & $48(72.7 \%)$ & 1.00 & \\
\hline \multirow{2}{*}{ rs2243289 } & Co-dominant & $\mathrm{G}$ & $43(15.4 \%)$ & $18(27.3 \%)$ & $2.07(1.10-3.89)$ & $0.022^{*}$ \\
\hline & & G/G & $83(59.3 \%)$ & $19(57.6 \%)$ & 1.00 & \\
\hline & & G/A & $52(37.1 \%)$ & $13(39.4 \%)$ & $0.90(0.39-2.09)$ & 0.810 \\
\hline & A/A & $5(3.6 \%)$ & $1(3 \%)$ & $0.85(0.08-8.85)$ & 0.889 \\
\hline \multirow{2}{*}{ Dominant } & G/G & $83(59.3 \%)$ & $19(57.6 \%)$ & 1.00 & \\
\hline & G/A-A/A & $57(40.7 \%)$ & $14(42.4 \%)$ & $0.9(0.39-2.04)$ & 0.797 \\
\hline \multirow{2}{*}{ Recessive } & G/G-G/T & $135(96.4 \%)$ & $32(97.0 \%)$ & 1.00 & \\
\hline & A/A & $5(3.6 \%)$ & $1(3.0 \%)$ & $0.88(0.09-8.98)$ & 0.915 \\
\hline & --- & --- & -- & $0.91(0.44-1.88)$ & 0.794 \\
\hline Log-additive & G & $218(77.9 \%)$ & $51(77.3 \%)$ & 1.00 & \\
\hline & A & $62(22.1 \%)$ & $15(22.7 \%)$ & $1.03(0.54-1.96)$ & 0.918 \\
\hline
\end{tabular}

SNP: Single nucleotide polymorphism; OR: Odds ratio; 95\% CI: 95\% confidence interval;

$P$-value calculated by logistic regression analysis with adjustments for gender and age;

${ }^{*} P$-value $<0.05$ indicates statistical significance.

Table 7 Five SNPs in IL4 haplotypes and their associations with HNC risk

\begin{tabular}{ccccccccccc}
\hline & rs2243250 & rs2227284 & rs2243267 & rs2243270 & rs2243283 & \multicolumn{2}{c}{ Without Adjustment } & \multicolumn{2}{c}{ With Adjustment } \\
\cline { 8 - 11 } & & & & & & & OR (95\% CI) & $P^{\mathrm{a}}$-value & OR (95\% CI) & $P^{\mathrm{b}}$-value \\
\hline 1 & $\mathrm{~T}$ & $\mathrm{~T}$ & $\mathrm{C}$ & $\mathrm{G}$ & $\mathrm{G}$ & $0.99(0.80-1.24)$ & 0.963 & $1.00(0.80-1.24)$ & 0.965 \\
\hline 2 & $\mathrm{C}$ & $\mathrm{G}$ & $\mathrm{G}$ & $\mathrm{A}$ & $\mathrm{C}$ & $0.95(0.75-1.20)$ & 0.655 & $0.95(0.75-1.20)$ & 0.663 \\
\hline 3 & $\mathrm{C}$ & $\mathrm{T}$ & $\mathrm{G}$ & $\mathrm{A}$ & $\mathrm{C}$ & $0.67(0.48-0.94)$ & $0.020^{*}$ & $0.67(0.47-0.94)$ & $0.019^{*}$ \\
\hline 4 & $\mathrm{~T}$ & $\mathrm{~T}$ & $\mathrm{C}$ & $\mathrm{G}$ & $\mathrm{C}$ & $0.86(0.72-1.03)$ & 0.098 & $0.86(0.72-1.03)$ & 0.100 \\
\hline
\end{tabular}

Block comprised of the three closely linked SNPs rs2243250, rs2227284, rs2243267, rs2243270, rs2243283;

OR: odds ratio, 95\% CI: 95\% confidence interval;

$P^{\mathrm{a}}$-value calculated by Wald test;

$P^{\mathrm{b}}$-value calculated by Wald test and adjusted by gender and age;

${ }^{*} P$-value $<0.05$ indicates statistical significance.

\section{Figures}

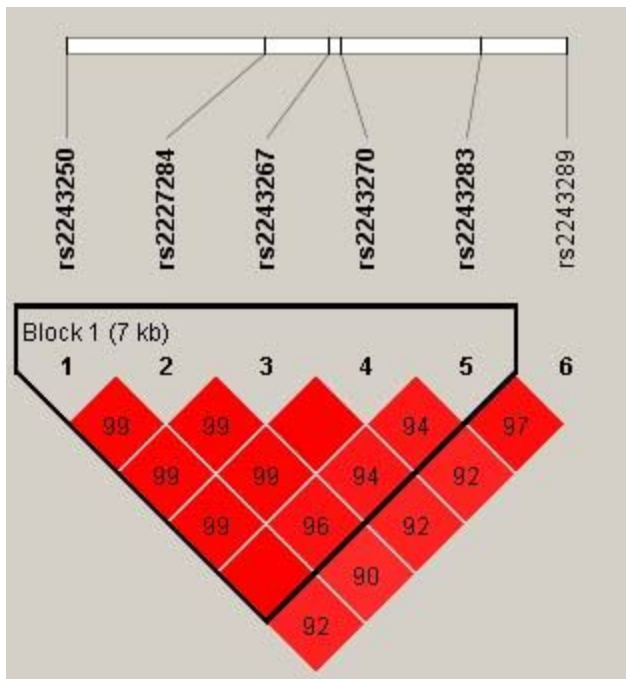




\section{Figure 1}

The haplotype block map constructed by candidate SNPs in IL-4. Block 1 includes rs2243250, rs2227284, rs2243267, rs2243270 and rs2243283; the linkage disequilibrium between two SNPs is indicated by standardized D' (red boxes). Abbreviations: SNP, singlenucleotide polymorphism; LD, linkage disequilibrium 